\title{
Novos modelos de prestação jurisdicional: a superação do paradigma da punitividade - uma leitura da Justiça Restaurativa a partir de Michel Foucault
}

New formats of jurisdiction: overcoming of the "paradigm of punitivity" - a reading of Restorative Justice from the philosophy of Michel Foucault

Nuevos modelos de jurisdicción: superación del paradigma de la punibilidad - una lectura de la Justicia Restaurativa desde Michel Foucault

Antônio Henrique Maia Lima ${ }^{1}$ Mauricio Serpa França ${ }^{2}$ Rafaela Maranho Gomes ${ }^{3}$

${ }^{1}$ Doutorando em Ciências Sociais pela Pontifícia Universidade Católica de São Paulo. Mestre em Desenvolvimento Local pela Universidade Católica Dom Bosco. Professor universitário na Faculdade Mato Grosso do Sul, cientista social e advogado.s: henrick_maia@hotmail.com, Orcid: http://orcid.org/0000-0002-5388-4749

${ }^{2}$ Mestrando em Educação pela Universidade Católica Dom Bosco. E-mail: mauricioserpa10@hotmail.com, Orcid: http://orcid.org/0000-0001-5439-949X

${ }^{3}$ Advogada atuante perante o Tribunal de Justiça do Estado de Mato Grosso do Sul. E-mail: rafaelamaranho@hotmail.com, Orcid: http://orcid.org/0000-0001-5430-282X 
Resumo: O presente artigo aborda a Justiça Restaurativa como um modelo contraparadigmático do sistema penal vigente. O modelo restaurativo se opõe ao punitivo e se apresenta como uma das soluções para o congestionamento da máquina judiciária e para a superpopulação presidiária brasileira, que leva o país às estatísticas mais negativas no mundo quando o assunto é respeito à dignidade da pessoa humana nos presídios. Assim, precisou-se tocar em temáticas como princípios gerais, princípios exclusivos, penas e suas modalidades, genealogias das penas e modos de aplicação das penas etc., para enfim abordar a Justiça Restaurativa, conceituando-a, contextualizando-a e problematizando-a à luz de um posicionamento filosófico crítico ao modelo punitivista, encabeçado por Michel Foucault e suas concepções acerca da punitividade.

Palavras-chave: Justiça Restaurativa; sistema penal; paradigma de punitividade; punição; pena.

\begin{abstract}
This article approaches Restorative Justice as an anti-paradigmatic model of the current penal system. The restorative model opposes punishment and is defined as one of the solutions to the congestion of the judicial machine and the large Brazilian prison population, which leads the country to the most negative statistics in the world, when it concerns the dignity of the human person in the prisons. It was necessary to touch topics such as general principles, exclusive principles, penalties and their modalities, a history of sentences and ways of applying penalties etc. to finally approach Restorative Justice, conceptualizing it, contextualizing it and problematizing it from a philosophical position critical to the punitive model, carried out by Michel Foucault and his conceptions of punitivity.
\end{abstract}

Keywords: Restorative Justice; criminal system; punitiveness paradigm; punishment; penalty.

Resumen: Este artículo aborda la Justicia Restaurativa como un modelo contraparadigmático del sistema penal actual. El modelo restaurativo se opone al punitivo y se presenta como una de las soluciones a la congestión de la maquinaria judicial y a la sobrepoblación carcelaria brasileña, lo que lleva al país a las estadísticas más negativas del mundo cuando el tema es el respeto a la dignidad de la persona humana en las cárceles. Por lo tanto, fue necesario tocar temas como principios generales, principios exclusivos, sanciones y sus modalidades, genealogías de sanciones y modos de aplicación de sanciones etc., para finalmente abordar la Justicia Restaurativa, conceptualizándola, contextualizándola y problematizándola a la luz de una posición filosófica crítica sobre el modelo de punibilidad, encabezado por Michel Foucault y sus concepciones sobre la punibilidad.

Palabras clave: Justicia Restaurativa; sistema penal; paradigma de la punibilidad; punición; pena. 


\section{CONSIDERAÇÕES INICIAIS}

Em vista do desenrolar da história e dos avanços diante das demandas sociais a partir das diversas discussões levantadas e suscitadas através do campo do direito, o presente texto visa expor novos modelos de prestação jurisdicional no âmbito penal, com o intuito de extrapolar o caminho das falhas e das ineficiências do sistema punitivo, tendo como ponto de discussão a Justiça Restaurativa. Com o crescimento da criminalidade e da população carcerária no Brasil, surge, a partir de demandas específicas, formas outras de resolução de conflitos visando à construção de respostas diante dos anseios e necessidades das pessoas envolvidas em conflitos oriundos da prática de um crime.

Os pontos que serão demonstrados no decorrer do presente trabalho vão mostrar outro meio de se buscar justiça, de forma menos formal, mais célere, mais doméstica, porém efetiva, que visa não somente à punição dos culpados, mas à reconstrução dos elos perdidos a partir da conduta delituosa, e vão problematizar a realocação da posição de sujeito na resolução da lide por parte do Estado para o indivíduo. A presente pesquisa, elaborada a partir de revisão bibliográfica, aborda a Justiça Restaurativa como forma de prestação jurisdicional, que denuncia o reconhecimento por parte do Estado de sua impossibilidade iminente e factual de gerir diretamente a resolução das lides, abrindo mão da cadeira de definidor da pena e condutor absoluto do processo, passando a levar em consideração a busca pelo consenso, no acordo entre todas as partes envolvidas mais a comunidade, empenhados em prestar uma solução para um crime que tenha ocorrido; assim, esse mesmo Estado se vê na obrigação de reconhecer sua incapacidade e ineficiência de gerir as penas privativas de liberdade como paradigma punitivo que se instaurou nos últimos séculos.

A respeito da Justiça Restaurativa, tem-se que esta seja um modelo de justiça que, além de ser voluntário, não tem formalidades em excesso; embora respeite alguma formalidade, ela é regida pelo princípio da informalidade. Utiliza a mediação, a conciliação e a transação como meios para conseguir a restauração e a ressocialização, para que o dano sofrido pela vítima seja reparado e o elo com o ofensor seja socialmente recomposto e, 
também, que o infrator seja inserido de volta socialmente, exercendo sua cidadania. O modelo restaurativo tem como base fundamental o diálogo, tido como instrumento apto a "curar" os conflitos, ampliando o acesso e o protagonismo das pessoas perante a Justiça, de forma que esta, enquanto poder público, ao menos possa atender às demandas de maneira mais competente, conveniente e digna. O modelo equivale a uma tentativa de quebra do paradigma punitivo, firmado em valores que têm como principal fundamento a reparação dos danos provenientes do crime causados às partes envolvidas - vítima, ofensor e coletividade - e, quando possível, a reconstrução das relações danificadas. Apresenta-se como uma possibilidade ao modelo para além do retributivo, pretendendo a complacência por alterações mais profundas e concretas diante das ineficiências do sistema penal.

A aplicação da tal justiça pode ser para crimes considerados mais leves ou também aos mais graves. Contudo, no Brasil, na maioria das vezes ela é utilizada nos crimes mais leves, devido ao fato de não se ter estrutura apropriada para crimes considerados mais graves, diante da cultura da punição vigente no nosso sistema legal. Em outros países, os crimes mais graves são escolhidos para a utilização do método, devido ao fato de serem mais perceptivos os ganhos com o modelo restaurativo. Assim, objetiva-se com a presente pesquisa demonstrar a possibilidade de aplicação da Justiça Restaurativa no Direito Penal Brasileiro, resgatando os valores essenciais da dignidade da pessoa humana quanto à prestação do serviço jurisdicional. Pretende-se ainda identificar os aspectos facilitadores e dificultadores na efetivação da Justiça Restaurativa no âmbito do direito penal pátrio.

O item intitulado "Princípios da Justiça Restaurativa" apresenta quais são os valores maiores desse modelo de justiça, as estruturas fundantes do modelo restaurativo. Fala-se, pois sim, de dois tipos principais de princípios: os da Justiça Restaurativa e os exclusivos da Justiça Restaurativa. Optou-se por essa divisão, pois os primeiros são partilhados por praticamente toda a esfera do nosso direito penal, ao passo que os últimos dizem respeito praticamente ao modus operandi da Justiça Restaurativa e, por isso, são "exclusivos".

No item "Das penas", serão discutidos os tipos de pena à luz das problematizações de Michel Foucault, além de algumas colocações a respeito 
da execução penal em determinados tipos de pena. Esse ponto de discussão se justifica em razão da guinada semântica que se dá ao se falar de "pena" no caso da Justiça Restaurativa, visando demonstrar como se encontra presente no nosso ordenamento uma cultura de punição, aqui chamada de paradigma da punitividade.

No item "Da superação do paradigma da punitividade pela Justiça Restaurativa", esse modelo de justiça será contextualizado a partir das apreciações de autores sobre a questão da pena. Entende-se ser frutífera a pesquisa de Michel Foucault a respeito da forma como a pena é tratada no Ocidente historicamente, bem como algumas hipóteses a respeito da criação do que se chamou de "cultura da punição" na maioria dos sistemas penais ocidentais. Ademais, será discutido o conceito desse modelo, breve histórico sobre o seu surgimento no mundo, breve histórico sobre seu surgimento no Brasil e as formas de aplicação, respeitando o que já se tem consubstanciado em lei, como uma "forma" brasileira de aplicação da Justiça Restaurativa.

\section{PRINCÍPIOS DA JUSTIÇA RESTAURATIVA}

O presente item tem por meta discorrer sobre o tema "princípios da Justiça Restaurativa" e "princípios exclusivos da Justiça Restaurativa", visto se tratar de um assunto que demonstra o propósito das técnicas restaurativas, que é, justamente, de que o "infrator" repare o mal causado à vítima, de forma que atenda às necessidades de ambos. É inevitável falar das diretrizes básicas a que as técnicas restaurativas se encontram sujeitas, bem como as teorias que norteiam os assuntos que lhes são pertinentes. Desse modo, os fundamentos visam fazer com que o objetivo restaurativo seja atingido dentro dos critérios para a efetividade da justiça vigente. No que concerne aos princípios da Justiça Restaurativa, "[...] existem poucas formulações objetivas dos princípios que regem essa abordagem, e neste aspecto, elencam-se os seguintes: Voluntariedade, Consensualidade, Confidencialidade, Celeridade, Urbanidade, Adaptabilidade e Imparcialidade" (BIANCHINI, 2012, p. 110). Vejamos um pouco de cada um deles:

O princípio da voluntariedade reflete a atuação dos envolvidos voluntariamente, sem que sofram coação, constrangimento ou obrigatoriedade. 
Dessa forma, no momento em que as autoridades sugerirem a resolução do conflito por meio da Justiça Restaurativa, as partes devem ser esclarecidas sobre o método, o que representa os direitos envolvidos e a forma de atuação (BIANCHINI, 2012, p. 118). Ao se apresentar o método da Justiça Restaurativa, existe a obrigatoriedade de haver uma explicação para as partes, demonstrando seus efeitos, a fim de despertar o interesse dessas a participarem do processo e terem ciência do que estão findando.

A explicação deve incluir o processo judicial para que as partes possam compreender e comparar as respostas que podem ser alcançadas. Tal procedimento traz maior segurança quanto à oportunidade oferecida, minimizando, assim, arrependimentos ou hesitações provenientes de dúvidas não esclarecidas (BIANCHINI, 2012, p. 119).

A voluntariedade das partes deve se dar de forma inequívoca, não podendo haver margens para qualquer tipo de coerção, constrangimento ou obrigatoriedade. Tal princípio deve ser obedecido por todas as partes do processo, no qual o conciliador não pode exercer tipo de influência algum nas decisões, seja do infrator, seja da vítima.

O princípio da consensualidade deriva do princípio da voluntariedade e sua aplicação se dá em todo o processo restaurativo. Visa demonstrar a responsabilidade do infrator, por ele mesmo, inclusive, através do reconhecimento, bem como o conhecimento dos fatos por ambas as partes. Um sinônimo de consensualidade é a concordância de opiniões sobre um tema, ou seja, o infrator e a vítima devem se voluntariar para participar do método restaurativo, estando presentes, então, os princípios da voluntariedade e consensualidade. O princípio sob comento deve ser empregado no decorrer da abordagem, na qual as partes obrigatoriamente não só concordaram com a participação, mas também compreendem de forma geral todo o procedimento e do que se trata o instituto da restauração, acordando sobre o funcionamento, regras, andamento e os princípios utilizados. O consenso sempre será claro e objetivo quanto à participação, aos fatos fundamentais e à responsabilidade do agressor (BIANCHINI, 2012, p. 124). A partir do princípio da consensualidade, são obtidos os acordos e as decisões mais críveis, tanto para o infrator quanto para a vítima, coisa que dificilmente as sentenças proferidas pelos magistrados conseguiriam abarcar, defendendo a liberdade 
quanto à forma de comunicação e afastando a excessiva formalidade que é encontrada no Poder Judiciário Institucionalizado (SALIBA, 2009, p. 126).

A confidencialidade é protegida do início ao fim do procedimento restaurativo, no qual todos os que estão comprometidos com a situação têm a obrigação de respeitar o sigilo do que foi discutido em seu decorrer, estendendo também a comunicação de informações que tenham caráter ético profissional, como as cedidas por advogados e médicos (BIANCHINI, 2012, p. 127). Em síntese, o princípio garante que os dados coletados no decorrer do método restaurativo não poderão ser acessados ou compartilhados em outros meios legais, bem como não serão anunciados a instituições sem prévia comunicação e autorização do infrator e também da vítima. 0 método restaurativo possui caráter informal, devido a isso, levando em conta o dever do sigilo, Bianchini (2012, p. 128) resguarda que os depoimentos apresentados ao longo da fase restaurativa não podem ser reduzidos a termos ou aproveitados, seja qual for a outra finalidade. Diante disso, Gabbay (2013, p. 54-5) apresenta que:

A confidencialidade é um valor muito importante: para que possam se comunicar de forma aberta sem se limitar por desconfianças, os participantes precisam ter certeza de que o que disseram não será usado contra eles em outra oportunidade.

Ao utilizar o método restaurativo, preza-se pelo princípio da celeridade, pelo qual a parte deve ter a sensação de uma eficiência e celeridade na resolução do conflito. Ela precisa notar que o movimento restaurativo possui celeridade em relação ao processo judicial e no tocante à fase executória há de ser ainda mais célere, dado o fato de que as próprias partes pretendem resolver de forma mais rápida e simples, com o intuito de desafogar o Poder Judiciário. Essa celeridade se dá pela ausência daquelas formalidades que não são intrínsecas ao processo e acarretam o atraso em sua tramitação, pela oralidade dos encontros e pela desburocratização (BIANCHINI, 2012, p. 129). Apesar de a celeridade ser um dos princípios da Justiça Restaurativa, pode ser que o espaço de tempo seja afetado, devido à agilidade nos procedimentos, os quais dependem do infrator, da vítima e do conciliador, que almejam a restauração do convívio e, consequentemente, o ressarcimento dos bens e, por fim, a ressocialização. 
No que concerne à informalidade, Gabbay (2013, p. 51-2) apresenta que ela é uma das notáveis características da mediação, não se prendendo em regras que são impostas. O papel do mediador é o de utilizar meios plausíveis para melhor desenvolver a audiência, prezando pela busca da solução do conflito e pela boa comunicação das partes, mas sempre de maneira imparcial. O método restaurativo é composto por início, meio e fim. Realizada uma análise das audiências que são efetivadas e são consideradas infrutíferas, sem tipo algum de acordo, não há motivos para dar sequência ao processo através do meio restaurativo, devendo este ser remetido para a justiça comum.

O princípio da urbanidade tem como objetivo o cumprimento de determinadas regras por aqueles que participam da Justiça Restaurativa, com o intuito de relacionamento agradável e para manter o equilíbrio das relações, tendo de existir no relacionamento das partes e na aceitação das regras e procedimentos próprios do modelo restaurativo de solução de conflitos (BIANCHINI, 2012, p. 130). Determinados códigos e condições necessitam ser respeitados e seguidos por todas as partes envolvidas, até mesmo pelo facilitador ou mediador que estiver presente. Embora o modelo restaurativo seja menos ritualístico que o modelo judicial, ainda exige o respeito a determinados ritos que lhes são caros.

Há ainda de se prezar pelo princípio da adaptabilidade em relação às diferenças entre o método restaurativo e o método judicial comum; uma das mais evidentes é a capacidade do primeiro de se adequar ao caso concreto. A despeito de ter um procedimento que deve ser seguido, o princípio da adaptabilidade facilita para que as partes entrem em um acordo, com a intenção de reduzir as tensões existentes e, com isso, solucionar o problema que fora criado. As situações apresentam peculiaridades distintas, por isso devem ser respeitadas para a efetivação do conceito de justiça que a restauração impõe para as partes. Conforme Bianchini (2012, p. 132), o princípio da adaptabilidade engloba a forma de aplicação, podendo ser pela conciliação, mediação, reunião ou círculos. Gabbay (2013, p. 54) recorda que: "informalidade não significa falta de critérios nem indisciplina". Isso quer dizer que a informalidade não tem sentido de "anarquia" do processo restaurativo, no entanto responderá às necessidades do caso concreto e 
será célere, abstendo-se os desgastes das partes no decorrer do processo. 0 fundamental objetivo do princípio em tela é alcançar uma maior efetividade plausível no método, no qual a forma de aplicação é definida em cada caso, como um instrumento para efetivar as ações que alcancem a restauração (BIANCHINI, 2012, p. 132).

Ao falar de processo, seja da justiça comum, seja da Justiça Restaurativa, deve-se verificar o princípio da imparcialidade da autoridade competente. Contudo, como já demonstrado, não existe nenhuma intervenção das autoridades judiciais no processo restaurativo, assim cabe ao mediador a aplicabilidade deste princípio. O mediador não poderá se envolver emocionalmente com as frustrações e os anseios do infrator e da vítima, também não poderá diferenciar nenhum integrante, pois o seu envolvimento influenciará de forma negativa no andamento do processo restaurativo (BIANCHINI, 2012, p. 133).

A função do mediador é administrar, por meio da comunicação, as diferenças entre as pessoas envolvidas em determinado conflito, oferecendo igualdade de condições para elas se expressarem, sem a finalidade de descobrir quem está certo ou errado, mas poderem entender o ponto de vista de cada um (QUEIROZ, 2011, p. 100).

Por fim, o desacordo existente deve ser solucionado com profissionalismo e cuidado, para não surgir um novo confronto entre as partes ou ainda uma solução injusta para o infrator ou para a vítima.

Superada a apresentação dos princípios basilares da Justiça Restaurativa, debrucemo-nos sobre os princípios exclusivos da Justiça Restaurativa, ou seja, aqueles que dizem respeito ao modo de operar desse modelo de justiça. O primeiro deles é o princípio da não punição e da reparação do dano. Segundo Caravellas (2009), o princípio em questão se justifica no fato de que o crime provoca a ruptura na relação entre dois indivíduos e é desejável ao bem-estar da sociedade que essa relação seja reconstituída, não interessando ao modelo restaurativo impor uma penalidade ao infrator, mas contribuir para que haja, sim, uma responsabilização, de forma a fazer com que ele reconheça seu erro e, por consequência, disponha-se a reparar o dano causado. Ainda segundo a autora, os danos que devem ser restaurados são os materiais, morais ou emocionais e a 
solução pode se dar de forma multifacetada, sendo, por exemplo, para além de uma compensação financeira, como pedidos de desculpas, firmação de compromisso de tratamento para vícios quaisquer, prestação de serviços, sem contar que o próprio método restaurativo, por suas especificidades, na maior parte das vezes já proporciona à vítima de imediato uma reparação moral ou emocional pelo simples fato de conceder-Ihe empoderamento diante da situação. Quando se tem possibilidade de a vítima ser ouvida e de expor as aflições, sendo atendida e apoiada, a solução para o conflito é alcançada mais facilmente, a partir das próprias conclusões dos envolvidos.

O procedimento restaurativo é dialógico e oral, logo, deve se basear também no princípio do diálogo e do respeito mútuo, que parte do diálogo livre e da escuta recíproca de todos os envolvidos, não havendo hierarquia ou predominância na participação de qualquer uma das partes e da comunidade, tampouco do mediador ou facilitador. Na restauração, todas as partes estão em igualdade de condições (CARAVELLAS, 2009).

Conforme Caravellas (2009), o reconhecimento da responsabilidade ativa pelo infrator é o mais fundamental dos passos para se chegar ao acordo restaurativo tão almejado, uma vez que ele também participa da elaboração do acordo e contribui ativamente para a busca de soluções do conflito instaurado. Essa responsabilidade ativa, na qual o ofensor reconhece que praticou o delito e se predispõe voluntariamente a se reunir com a vítima, conhecendo, através do relato dela, de que modo ela foi afetada pelo crime e compartilhando sua dor, favorece um ambiente de empatia e, a partir daí, juntam-se as partes em um esforço para reparar o prejuízo mediante a construção do plano de ação a ser executado por todos.

É característico da Justiça Restaurativa a presença de elementos que não compõem parte, a comunidade, o que implica no princípio da participação comunitária. Além dos diretamente envolvidos no fato, participam dos círculos restaurativos os facilitadores, pessoas da comunidade previamente capacitadas para conduzir os trabalhos, além dos apoiadores levados pelas próprias partes com vistas à criação de um ambiente o mais intimista possível. Esses apoiadores podem ser familiares, amigos, vizinhos, advogados, professores, psicólogos, enfim, qualquer pessoa com quem a vítima e o ofensor se sintam seguros e que considerem importantes na discussão 
do problema. Essa é uma ferramenta que reforça o clima de confiança e de empoderamento das partes, dado que ela leva consigo um "time" de sua escolha. Também participam os grupos de suporte, como associações ou entidades atuantes na questão que gerou o conflito, as quais estarão presentes se as circunstâncias do fato guardarem relação com o seu campo de atuação.

\section{DAS PENAS}

A pena no direito penal é interpretada à luz de um processo histórico e cultural. Segundo Noronha (2003), a literatura divide o estudo da pena em três fases distintas:

1) Vingança Privada - aqui predominava uma atmosfera de vingança, estando em vigência o princípio ou a Lei de Talião, o "olho por olho, dente por dente", e também era possível a "composição", segundo a qual o ofensor, desde que estivesse em condições para tal, comprava a sua impunidade, pagando ao ofendido ou seus representantes com dinheiro, gado, armas e tudo mais que pudesse apetecer a vítima. Ambos os princípios, o Talião e a Composição, estão contemplados no célebre Código de Hamurabi de 1780 a.C., tido como um dos mais antigos ordenamentos jurídicos da história humana.

2) Vingança Divina - tendo como ponto de justificativa o enorme poder político e econômico da Igreja Católica ao longo da história europeia, surge um direito que the é específico, o Direito Canônico, a partir do século XII. O fundo intencional desse tipo de direito era pretensamente o de humanizar e espiritualizar as penas, consideradas demasiado cruéis, incorporando a essas um "espírito cristão". Ocorre que, mesmo assim, as penas permaneceram tão ou até mais cruéis que antes, atribuindo-se a pena de morte quase que indiscriminadamente, mediante a forca, a fogueira, o afogamento, a estrangulação, o arrastamento, a evisceração, o enterramento ainda com vida, o esquartejamento e outras formas de tortura que culminariam na incapacidade, na amputação e na morte.

No século das luzes, Beccaria, influenciado pelo movimento filosófico-humanitário que tem o traço marcante de Voltaire, Rousseau e Montesquieu, 
escreveu o seu magnus opus "Dos Delitos e das Penas" (1764), que foi uma crítica ao sistema vigente e ao monopólio da aplicação das duras penas por parte da igreja e do Estado. No entanto Beccaria não colocou em questão a soberania do Estado, tampouco o poderio do Direito Canônico. Sua obra se resume a um esboço de demarcação de alguns limites razoáveis entre as "Justiças de Deus e dos Homens", diferenciando as noções de pecado e de crime, proclamando uma utilidade social para a pena, desvestindo-a do caráter de "vingança legalizada".

3) Vingança Pública - o Estado chama para si a responsabilidade de definir quais as condutas constituiriam crimes e suas respectivas sanções, despossuindo a sociedade do direito de punir com suas próprias mãos, estabelecendo, assim, uma nova era no que diz respeito às penas, marcada por um caráter preventivo, retributivo e ressocializador através de um "Direito Penal".

No primeiro momento, a punição se apresentava quase sempre como sendo desproporcional ao delito. Segundo Foucault (1999), há um caso bastante emblemático, o do francês Damiens, que foi condenado em março de 1757 a pedir perdão publicamente diante da porta principal da Igreja de Paris, levado e escoltado nu em uma carroça, carregando com a mão esquerda uma vela de cera acesa de $1 \mathrm{~kg}$, levantada aos céus para que as gotas de cera caíssem sobre sua cabeça e corpo. Na referida carroça, na praça de Gréve e sobre um cadafalso, o pobre homem seria erguido, apertado na altura dos mamilos, nos braços, nas coxas e nas panturrilhas, sendo que sua mão direita deveria segurar a faca com que cometeu o seu crime: um parricídio. A referida mão deveria ser banhada em enxofre e em seguida queimada, e nas partes em que estaria sendo apertado deveria ser atirado chumbo líquido quente, óleo fervente, piche em fogo, cera e enxofre derretidos, conjuntamente, e, como se não bastasse, o condenado teria seu corpo puxado e desmembrado por quatro cavalos rápidos e os seus quatro membros só poderiam ser reunidos ao corpo para serem todos consumidos pelo fogo, reduzidos a cinzas, e estas lançadas ao vento. Com o advento da Revolução Francesa, a mais célebre das penas capitais, a guilhotina entrou em voga, tendo levado, somente através deste instrumento, a cabeça de mais de quarenta mil pessoas. No entanto, com o lento passar do tempo, 
as penas vão sendo humanizadas. Determinados países vão abolindo as penas capitais ou as excessivamente humilhantes, como as penas corporais, as torturas, os suplícios e os trabalhos forçados. O atual pensamento é recuperar, educar ou reformar o condenado.

Existem vertentes de pensamento ou de interpretação da função da pena. Alguns entendem que a pena possui um caráter eminentemente retributivo (Teoria Absolutista), outros entendem que deve predominar o caráter preventivo da pena (Teoria Relativista) e há ainda aqueles que atribuem em pé de igualdade essas duas características da pena (Teoria Mista). Segundo nosso Código Penal (CP), de acordo com o seu art. 32, as penas podem ser: privativas de liberdade; restritivas de direito; e multa. $\mathrm{O}$ Código distingue duas penas privativas de liberdade, a de reclusão e a de detenção, sobre as quais incidem uma série de implicações de direito penal material e penal processual, tais como o regime de cumprimento a ser fixado na sentença condenatória e a possibilidade de concessão de fiança pela autoridade policial. A pena privativa de liberdade vem prevista em cada tipo penal incriminador e, ao seu final, servindo à sua individualização, que permitirá a aferição da proporcionalidade entre a sanção que é cominada em comparação com o bem jurídico por ele protegido.

De forma bastante sintética, podemos dizer que o regime fechado versa na permanência em ambiente prisional por tempo integral, tendo o condenado a faculdade de poder trabalhar internamente durante o dia e repousar no período noturno. O regime semiaberto, para o Código Penal, consiste na possibilidade de o preso ser transferido da penitenciária para uma "colônia penal" agrícola ou industrial, durante o período diurno, e retornar à penitenciária no noturno. Contemporaneamente, na prática, o preso tem uma prisão própria para tal regime em que lhe são oferecidas vagas de emprego na iniciativa privada, de modo que é possível que ele saia durante o dia para trabalhar e retorne à penitenciária em período noturno para repousar. Já o regime aberto, para o $\mathrm{CP}$, consiste na hipótese de que o condenado poderia ter autonomia durante o dia e passaria a noite e os feriados em uma casa de albergado ou prisão-albergue, onde teria acesso a cursos e palestras.

A pena restritiva de direitos é uma sanção penal que se apresenta como uma opção ou substituição à pena privativa de liberdade clássica, 
consistindo na supressão ou arrefecimento de um ou mais direitos do condenado. É uma espécie de pena alternativa que é aplicável aos crimes com menores graus de responsabilidade, com penas teóricas mais brandas. Esse tipo de pena está albergado ao princípio da proporcionalidade. Segundo ao artigo 43 do Código Penal: são penas restritivas de direitos a prestação pecuniária, a perda de bens e valores, a prestação de serviço à comunidade ou às entidades públicas.

Existem algumas ressalvas à aplicação da prestação pecuniária, por exemplo, a disposta no artigo 17 da Lei Maria da Penha, que veda a aplicação, nos casos de violência doméstica e familiar contra a mulher, de penas como cesta básica ou prestação pecuniária. Referido dispositivo veda também a substituição de pena que implique o pagamento isolado de multa. Já de acordo com o parágrafo 3 o do Código Penal, a perda de bens e valores implica a retirada do rol de propriedades do agente conforme o equivalente ao benefício que auferiu com o crime, além de privá-lo da vantagem, diminuindo seu patrimônio e desestimulando a reiteração. Presume a deslucratividade da atividade criminosa e o enfraquecimento do poder econômico do agente, servindo até mesmo para desmontar eventual estrutura criminosa existente. O que se arrecada com essa medida deve ser direcionado ao fundo penitenciário nacional.

O exercício da prestação de serviços comunitários ou públicos é aplicável somente às condenações superiores a seis meses de privação de liberdade e tem seus pormenores estabelecidos pela Lei de Execuções Penais, nos artigos 149 e 150, segundo os quais o juiz designa o local onde o condenado trabalhará gratuitamente, de acordo com suas aptidões, intimando-o dos dias e horários do cumprimento da pena. Se necessário o juiz poderá alterar a forma de execução da pena.

A interdição temporária de direitos se encontra detalhada nos artigos 47 do Código Penal. Segundo a lei, as penas de interdição temporária de direitos são: proibição do exercício de cargo, função ou atividade pública, bem como de mandato eletivo; proibição do exercício de profissão, atividade ou ofício que dependam de habilitação especial, de licença ou autorização do poder público; suspensão de autorização ou de habilitação para dirigir veículo; proibição de frequentar determinados lugares; proibição de 
inscrever-se em concurso, avaliação ou exame públicos. É de se ressaltar que não há pena efetiva, e sim uma suspensão do exercício de algumas atividades, por tempo determinado. Segundo o art. 47, II do CP, as medidas têm caráter retributivo (devido ao fato de o réu ser penalizado pelo crime recaindo sobre o trabalho ou atividades cotidianas) e caráter preventivo (impedindo que o Estado seja utilizado para caráter ilícito, se o condenado for servidor público).

A multa no direito penal não tem caráter indenizatório, mas sim retributivo. Isso significa que ela é aplicada como "punição". Está prevista entre os artigos 49 e 52 do Código Penal. Segundo o primeiro, a pena de multa consiste no pagamento ao fundo penitenciário da quantia fixada na sentença e calculada em dias-multa. Será, no mínimo, de dez e, no máximo, de 360 dias-multa. Vale aqui lembrar que há um problema de redação no referido artigo. Diferentemente da indenização cível, o destinatário da pena de multa não é a vítima, tampouco seus representantes ou mesmo entidades que eventualmente esta eleja para receber o quantum indenizatório. A pena de multa é aplica pelo Estado e é este o destinatário do valor arrecado a título de punição pecuniária. Ela não é alternativa à pena privativa de liberdade, mas concomitante a esta, desde que haja previsão expressa no tipo penal. Existem exceções a essa regra, no caso, o tipo penal deve apresentar a partícula "ou", dando um caráter alternativo à multa (exemplo do art. 163 do $\mathrm{CP}$, o crime de dano). É possível ainda que a multa seja resultado de uma transformação ou mutação da pena privativa de liberdade em pena de multa, devido à brandura da primeira. Segundo o artigo 60, parágrafo segundo do Código Penal: a pena privativa de liberdade aplicada, não superior a seis meses, pode ser substituída pela de multa, observados os critérios dos incisos II e III do art. 44 deste Código. Assim a pena de multa pode possuir um caráter substitutivo à pena privativa de liberdade. Os valores das penas de multa são quantificáveis em dias-multa, e, segundo o artigo 49 do Código Penal, o valor do dia-multa será fixado pelo juiz, não podendo ser inferior a um trigésimo do maior salário mínimo mensal vigente ao tempo do fato, nem superior a cinco vezes esse salário. Tais valores serão atualizados, quando da execução, pelos índices de correção monetária. 


\section{DA SUPERAÇÃO DO PARADIGMA DA PUNITIVIDADE PELA JUSTIÇA RESTAURATIVA}

De acordo com Brancher (2010), a justiça restaurativa não é apenas um modelo de solução de conflitos, mas um movimento comunitário de pacificação e de empoderamento de pessoas e de comunidades. Trata-se de uma mudança semântica a respeito do sistema penal, seus mecanismos, possibilidades de transformação, tendo como horizonte a formação de um conhecimento que se traduza em possibilidades de transformação social e de emancipação da cidadania. Ainda segundo Brancher (2010), nossa relação com a justiça enquanto ideal é nebulosa e confusa, permeada por uma série de aspectos sociais, políticos, econômicos e até mesmo antropológicos. Isso decorre de um histórico em que o papel de efetivar a justiça e a própria capacidade para isso é retirado dos cidadãos e delegado como competência exclusiva para o Estado. A "justiça institucional" se converte nos poderes atribuídos a determinados segmentos de servidores públicos e agentes políticos, esvaziando do povo, em simultâneo, esses mesmos poderes. Para além disso, muito pouco trabalhamos com a de justiça enquanto valor: "como a possibilidade de cada um compreender e exercer as relações de equilíbrio com o seu meio, sua comunidade, seu ambiente natural fica, no mais das vezes, oculto" (BRANCHER, 2010, p. 153).

A distância criada assim entre o exercício da função de "fazer justiça" envolve um componente de desresponsabilização de si e transferência para um terceiro (o Estado), que, por sua vez, delega refratariamente essa função para alguns de seus representantes, investindo-os de autoridade e "fé pública", o que permite que a sociedade se ausente nesse processo (BRANCHER, 2010). O papel da sociedade passa a ser apenas de entidade cobradora da prestação do serviço jurisdicional, sem que para isso precise "sujar as suas mãos". A forma mais simples, dentro da pouca condição dos membros da sociedade de acessar e fiscalizar o efetivo cumprimento dos serviços prestados pelo Estado, pela pouca e ineficiente educação, pela falta de transparência do próprio Estado e pela grande burocracia, é pela via mais comum: ver a camada mais superficial e grosseira da sensação de se estar fazendo justiça, isto é, a punição. Esse processo, ao longo de séculos, cria uma sociedade ansiosa e desejosa do castigo (FOUCAULT, 1999). 
Ainda, para Foucault (1999), a forma de punição típica que perdurou até o fim do século XVII e princípio do século XVIII na Europa, onde o sistema de governo monárquico predominou, foi o castigo. O castigo da pena aplicado aos condenados se travestia como um sofrimento físico incessante e brutal aplicado aos seus corpos. O autor narra contextos históricos desenvolvidos principalmente na França, com numerosas maneiras de aplicação de flagelo humano, em que o poder soberano do Estado mitigava qualquer forma de expressão dos direitos fundamentais inerentes à própria existência da pessoa enquanto sujeito de direitos. Com isso, podemos concluir e argumentar que o responsável por essa "preguiça cultural" da sociedade em solucionar seus próprios conflitos não é apenas a própria sociedade. Não se pode negar que o "fazer justiça com as próprias mãos", que por séculos foi considerado digno de honra, passou, inclusive, com o advento do modelo societário moderno e do Estado-Nação, a ser criminalizado. Um exemplo é o nosso próprio Código Penal, que tipifica o exercício arbitrário das próprias razões no seu art. 345, em que o fazer justiça pelas próprias mãos, para satisfazer pretensão, embora legítima, salvo quando a lei o permite, é punível com a detenção ou multa. Existe, portanto, um elemento extrínseco que deve ser considerado. Em todo caso, as pessoas ao longo das gerações são desencorajadas a praticarem por si a resolução de conflitos, tornando-se dependentes de uma justiça estatal, o que gerou, por sua vez, uma sociedade afeta ao suplício dos criminosos.

Retornando a Foucault (1999), apenas para exemplificar a crueldade da apelação enquanto retribuição ao mal causado, o autor cita o corte de membros seguido de incêndio aos restos mortais, mutilações de cabeças seguidas de facadas lançadas ao peito, enforcamento seguido de banho em caldeira de água fervente e todas as formas possíveis e imagináveis de tortura e manifestação do poder sobre os corpos dos condenados. O espetáculo da punição era a forma de o Estado "prestar" contas do seu serviço jurisdicional para a sociedade que se encontrava sob sua jurisdição. Este método denotava a exortação do suplício, ou como Foucault (1999) mesmo definiu, "a arte equitativa do sofrimento", para traduzir a expressão máxima do poder estatal sobre os subordinados (a "economia do poder", segundo o autor), alimentados pela violência aplicada ao corpo do condenado, como um processo 
de reconstrução da ordem violada naquele instante. Tudo franqueado por um processo criminal sigiloso e inquisitorial, em que o saber era privilégio absoluto da acusação e onde o suplício se propagava enquanto agente do poder. Essa seria a maneira de garantir o sistema vigente e legitimá-lo enquanto poder de submissão do Estado sobre as massas de populações, sistema, aliás, que não se distancia do mesmo empregado nos dias atuais, na medida em que se continua a observar no poder do Estado sobre seus cidadãos a franca estratégia das classes dominantes em dar continuidade a este processo de adoração do suplício como sua própria manifestação de poder de classe, que encontra na prisão um meio de tornar o indivíduo apto à absorção inconteste das classes superiores normalmente amalgamadas às elites do poderio econômico. Assim, o corpo do condenado se tornava objeto do império do Estado, sobre o qual o soberano imprimia sua marca e deixava cair os efeitos de seu poder. O povo temeroso e reverencial a este poder enxergava, neste simbolismo exponencial, o caráter e a função de prevenção geral negativa da pena, servindo de testemunhas para que o suplício fosse reverenciado por todos. Um martírio corporal que era em simultâneo "um recibo" de um "bom serviço" e "um lembrete" ao povo do poder do Estado.

Foucault (1999) narra a mudança do paradigma do martírio infligido ao condenado, abordando a temática dos reformadores dos séculos XVIII e XIX, que, enxergando nos espetáculos de tortura do corpo do condenado o surgimento da compaixão popular, passaram a pleitear a supressão deles. Surgem as prisões como forma de manutenção da lei e ordem, de novo paradigma para legitimação do poder estatal, validação do contrato social ante uma mudança nas relações sociais, causada principalmente pela economia de mercado e circulação de bens de consumo, alvos constantes de pilhagens e de roubos.

Para dar apoio a esta nova dinâmica do poder, com a mudança de novos bens jurídicos a serem protegidos, o sistema penal é concebido para deslocar-se do eixo de vingança do Estado soberano para a defesa da sociedade burguesa. É realçada a existência de princípios mínimos a serem observados na aplicação da pena, que não mais atinge o corpo do condenado (antes coisa do Estado, e agora "bem social, objeto de uma apropriação 
coletiva e útil"), mas sim sua alma. Michel Foucault (1999) identifica a disciplina mantida nas prisões como algo a moldar os corpos dos indivíduos, enquanto processo de docilização para sujeição da vontade e do controle da produção de energia individual voltados ao capitalismo. Ele nos mostra uma clara visão dos processos de adestramentos desenvolvidos no cárcere, semelhantes em seminários, quartéis, escolas, locais em que a supressão do tempo é um forte aliado neste processo de sujeição. Identifica a aprendizagem corporativa como forma de desenvolvimento de programas bem definidos para atendimento deste estado de coisas, pautado pela dominação do sistema e pela sujeição dos condenados.

Para Foucault (1999), as práticas disciplinares que tornam os homens domáveis (e por que não dizer domesticáveis), próprias da prisão, suplantam a órbita daquele meio e têm alcance que transplanta muito além das barreiras impostas pelas muralhas correcionais, transmudando-se e constituindo-se em verdadeiras armas tecnológicas de poder, a alcançar todos os membros da sociedade em que se encontram contextualizadas. O autor conclui pelo paradoxo da realidade e do modelo coercitivo de correção franqueado pelo aprisionamento, na medida em que, enquanto o modelo pensado desejaria reprimir e reduzir a criminalidade, selecionar e organizar a delinquência, em verdade passa a contribuir para a manutenção dela, como um círculo vicioso e sem fim. Esta forma de constatar o sentido de punir o indivíduo põe em xeque tanto alguns estudos liberais que veem na prisão moderna algo de mais avançado em termos de humanização das práticas penais, outrora tidas como desumanas, quanto a concepção marxista mais radical, que vê nas transformações das penalidades apenas um instrumento a mais a dar sustentação ao modo de vida capitalista calcado na produção de massa.

Esses valores, há muito incorporados, talvez acabem gerando um funcionamento deficitário das representações sociais que fariam a crítica de um sistema de valores antagônicos àqueles que elas representam, quando não por conivência, por falha, por impossibilidade, por incapacidade de enxergar sobre si mesmo, o conjunto (BRANCHER, 2010). A mediação assume, nesse contexto, diferentes dimensões. A primeira delas, para Brancher (2010), é a dimensão transgeracional, tendo como papel primordial a quebra de um 
paradigma: "Até aqui, temos praticado um valor de justiça essencialmente violento: automaticamente, instala-se como método de alguém que diz a vontade da lei, seja ela de qualquer esfera legislativa ou normativa, do Congresso Nacional, da direção da escola, seja do traficante que elimina literalmente quem a descumpre" (BRANCHER, 2010, p. 154). Esse modelo preza por uma justiça que nega sua própria possibilidade de ser uma justiça inserida na perspectiva da alteridade. Segundo essa perspectiva, não existe o exercício da justiça sem o respeito e a interação com o outro e uma autêntica possibilidade de expressão dos sujeitos interessados e envolvidos na atividade jurisdicional. Ainda que não seja nessa geração o pleno transcorrer desse paradigma, temos a tarefa de transformar as estruturas institucionais para que as próximas gerações vislumbrem um horizonte para além de um sistema violento de controle social em que nossa geração se encontra imersa (BRANCHER, 2010).

Enquanto modelo crítico, a Justiça Restaurativa surge como proposta em que as partes têm a chance de se reunir para decidir coletivamente como vão lidar com as circunstâncias decorrentes de um ato considerado ofensivo e planejar um futuro a partir disso.

Este modelo vai surgir a partir da crítica à compreensão do conceito de crime. Crime é uma violação ao Estado, definida pelo descumprimento da lei e pela culpabilidade. A justiça determina culpa e administra pena diante de procedimento contencioso entre o ofensor e o Estado, dirigido por regras sistemáticas. A partir da visão restaurativa de crime, vamos compreendê-lo como uma violação das pessoas e dos relacionamentos. A Justiça Restaurativa envolve o ofensor e a comunidade, na busca de soluções que promovem acordo, reconciliação e segurança (BRANCHER, 2010, p. 154-5).

Ainda para Brancher (2010), "não perguntamos às vítimas o que elas querem da justiça - se perguntamos, nos desorganizamos e perdemos a tarde ouvindo a dor, o desabafo, o sofrimento". O lugar da vítima no modelo vigente não existe, pois este é assumido por um ente do Estado - o Ministério Público. Um processo colaborativo, portanto, vem para assegurar a reconciliação e a reparação dos danos, trazendo vítimas, ofensores e comunidades para a discussão direta do que lhes parece ser melhor. Essas pessoas não vêm para figurar no papel de litigantes ou testemunhas de um 
processo penal, mas sim como construtores colaborativos de uma solução. Se no modelo punitivo o foco é a punição, no modelo restaurativo o foco é a reparação de danos. Assim, "faz-se a transição de uma justiça que fere para uma justiça que cura" (BRANCHER, 2012, p. 155).

Portanto podemos sintetizar a Justiça Restaurativa como "toda ação que é primariamente orientada para a justiça, ao restaurar o dano causado por um crime" (WALGRAVE, 2006), bem como "uma forma de tratar a questão criminal voltada para a reparação do dano causado às vítimas e à reconstrução das relações humanas afetadas pelo delito" (CARAVELLAS, 2009, p. 121).

Diante dessas informações e conceitos, precisamos nos familiarizar com alguns conceitos fundamentais da Justiça Restaurativa, de acordo com a Resolução 2002/12 da Organização das Nações Unidas. Veja-se:

Processo restaurativo significa qualquer processo no qual vítima e 0 ofensor, e, quando apropriado, quaisquer outros indivíduos ou membros da comunidade afetados por um crime, participam ativamente na resolução das questões oriundas do crime, geralmente com a ajuda de um facilitador. Os processos restaurativos podem incluir a mediação, a conciliação, a reunião familiar ou comunitária (conferencing) ou círculos decisórios (sentencing circles).

Resultados restaurativos incluem respostas e programas tais como reparação, restituição e serviço comunitário, objetivando atender as necessidades individuais e coletivas e responsabilidades das partes, bem assim promover a reintegração da vítima e do ofensor.

Segundo Jaccound (2005), existem ainda três categorias ou modelos de aplicação da justiça restaurativa. O modelo centrado nas finalidades preza pelas finalidades sobre os meios, isto é, os processos restaurativos passam a ser secundários, possibilitando que processos diferentes, tal como a arbitragem, por exemplo, façam parte dos meios disponíveis para atingir as finalidades restaurativas. Existe, no entanto, um embate doutrinário quanto a esse modelo, dado que muitos autores recusam a aceitação desse tipo de ampliação de possibilidades restaurativas, sob o argumento de que, havendo ausência de diálogo entre as partes, não se tem efetivamente uma forma de Justiça Restaurativa. O modelo centrado nos processos considera que as finalidades restaurativas são secundárias aos processos restaurativos, pois 
seriam estes que definiriam um modelo de Justiça Restaurativa. Assim, por exemplo, por mais que o resultado da negociação tenha um fim retributivo, somente pelo fato de o processo ter sido conduzido pela negociação, consulta e envolvimento suficiente das partes, tais práticas fariam desse um modelo de Justiça Restaurativa (DIAS; MARTINS, s.d.). Essa visão também comporta duras divergências doutrinárias: uma vez que em um processo as partes acordem pela pena de prisão ou mesmo por uma pena que termine na humilhação pública do ofensor, não será cumprida a finalidade restaurativa, que é reconciliadora, desvirtuando-se, assim, os princípios da própria Justiça Restaurativa (JACCOUND, 2005).

O modelo centrado nos processos e nas finalidades define como prática de Justiça Restaurativa aquela em que os processos negociados tiverem a finalidade restaurativa. Trata-se de uma visão restrita da Justiça Restaurativa. "Isto impõe à mesma, condições [...] que concentram todas as possibilidades de serem aplicadas a situações que requeiram boa vontade de ambas as partes no que diz respeito à infração. [...] conduz inevitavelmente a confinar a justiça restaurativa à administração de infrações sumárias o que, evidentemente, reduz seu potencial de ação" (DIAS; MARTINS, s.d., p. 7). Além disso, "se inscreve nas práticas de mecanismos civis e não de mecanismo jurídicos" (JACCOUND, 2005, p. 171). Nesse sentido, a Justiça Restaurativa seria colocada mais uma vez sob o império da máquina jurisdicional institucionalizada, eliminando sua potência de ação. Uma corrente mais abolicionista penal contesta veementemente essa forma restrita de concepção da Justiça Restaurativa, que, por outro lado, é defendida pelos mais positivistas.

A Justiça Restaurativa surge em um contexto de guinada de compreensão da própria ideia de justiça. A marcante frase de Brancher (2010) é muito pedagógica nesse sentido: uma justiça que cura, como modelo de justiça, ao invés de uma justiça que fere. Ainda segundo o autor, o modelo de justiça que restaura se preocupa com a responsabilidade dos envolvidos, e não somente com a vingança (através da pena) ou com o perdão (através do modelo reabilitador), prezando, pois sim, pela responsabilidade.

Segundo Lode Walgrave (2006), as gêneses dos três modelos (penal, reabilitador e restaurativo) podem ser obtidas a partir de um mapeamento 
(modelo apresentado na figura $X$ ) que leva em consideração cinco variáveis: o ponto de referência; os meios; os objetivos; a posição das vítimas; e o critério de avaliação e contexto social. O ponto de referência é o delito: no modelo penal, discute-se o crime em si; o modelo reabilitador foca no indivíduo delinquente; e o modelo restaurativo, em quais são os danos, o tratamento e as terapias. O restaurativo tem como objetivo a obrigação de restaurar; o modelo penal objetiva o equilíbrio moral, e a pena é o mal que vai compensar o mal causado. A adaptação é o objetivo do modelo reabilitador; a neutralização dos erros é a expectativa restaurativa. As vítimas são secundárias em ambos os modelos, seja o punitivo, seja o ressocializante ou o terapêutico. Na Justiça Restaurativa, a posição das vítimas passa a ser central, porque é a elas que temos de fazer as perguntas fundamentais: doeu? O que você precisa? Quem pode te ajudar?

Assim, surge a Justiça Restaurativa com a intensão de corrigir as problemáticas oriundas da ineficiência do modelo punitivo estabelecido como paradigma de sistema judicial.

\section{EM TOM DE CONSIDERAÇÕES FINAIS}

A Justiça Restaurativa surge com a missão de derrubar o paradigma positivista e punitivista vigente na maioria dos ordenamentos jurídicos ocidentais. Ela surge com a intenção e a missão de corrigir as problemáticas oriundas da ineficiência do modelo punitivo e, especificamente no Brasil, em um contexto de crise profunda, ela aparece como uma alternativa para a verdadeira crise humanitária experimentada pelo nosso sistema carcerário. Tem ainda a missão de reconciliar a cidadania com a experiência da "justiça" enquanto ideal; restaurando entre os cidadãos não só o vínculo perdido com a prática de um crime, mas também o vínculo perdido com a possibilidade de se ter uma justiça sem que esta seja necessariamente uma determinação do Estado. Nesse ponto, a Justiça Restaurativa tem a potência de sanar os efeitos negativos de um processo histórico, em que o papel de efetivar a justiça e a própria capacidade para isso foram retirados dos cidadãos e delegados como competência exclusiva do ente soberano, tendo, pois sim, um caráter para além do jurídico, também político. 
Enquanto modelo crítico ao paradigma punitivista, a Justiça Restaurativa surge como proposta em que as partes têm a chance de se reunir, dialogar entre si, decidir como vão lidar com as circunstâncias decorrentes de um ato considerado ofensivo e planejar um futuro a partir disso, ou seja, trazer à luz o problema a partir de suas próprias concepções. Ao adotar a justiça restaurativa, é possível a ressocialização de um apenado? É certo afirmar que a restauração bem-sucedida, em que as partes reconhecem suas falhas e suas responsabilidades e se predispõem, além de inventar uma solução, cumprir e fazer o que for necessário para que essa solução seja de fato resolutiva, permite a ressocialização de um apenado. Uma vez que o processo restaurativo parte promovendo a reflexão no infrator a respeito da própria conduta, levando-o ao reconhecimento de seu erro e assumindo a responsabilidade por ele, é plausível admitir que ele é ressocializador. Ademais, inúmeros casos de sucesso são verificados em diversos países e mesmo no Brasil, conforme se demonstrou. Assim, é irrefutável e inegável que a Justiça Restaurativa tem tido sucesso em seu caráter ressocializador.

É incontestável ainda que as experiências restaurativas no Brasil, a partir dos projetos-pilotos de Porto Alegre, São Caetano do Sul e Brasília, têm atestado, apesar da resistência do nosso sistema penal e da cultura da punição, que se trata de um caminho sem volta a mudança de pensamento no que diz respeito à solução dos conflitos penais. Cada vez mais, a tendência é de possibilitar e fomentar a resolução dessas questões no âmbito do diálogo, do acordo, da conciliação, desafogando o sistema judiciário e filtrando exponencialmente os casos que de fato se tornam um processo judicial em todas as suas fases.

Por fim, conforme já tenha restado claro, advoga-se pela manutenção, propagação e amadurecimento do nosso sistema restaurativo, a fim de ampliar, assim, os efeitos positivos da Justiça Restaurativa e diminuir não só o número de processos, mas também a população carcerária, elevando os índices de ressocialização por todo o país. 
Novos modelos de prestação jurisdicional: a superação do paradigma da punitividade uma leitura da Justiça Restaurativa a partir de Michel Foucault

\section{REFERÊNCIAS}

BECCARIA, Cezare. Dos delitos e das penas. Portal Domínio Público, [S.I.]: Ridendo Castigat Mores, 1764. Disponível em: http://www.dominiopublico.gov. br/download/texto/eb000015.pdf. Acesso em: jun. 2019.

BIANCHINI, Edgar. Justiça Restaurativa: um desafio à práxis jurídica. Campinas, SP: Servanda Editora, 2012.

BRANCHER, Leoberto. Justiça Restaurativa: para além do perdão e da vingança. In. UNESCO. Cultura de paz: da reflexão à ação - balanço da Década Internacional da Promoção da Cultura de Paz e Não Violência em Benefício das Crianças do Mundo. Brasília, DF: UNESCO; São Paulo: Associação Palas Athena, 2010. p. 153-7.

BRASIL. Decreto-Lei n. 2.848, de 7 de dezembro de 1940. Código Penal. Brasília, DF, 1940, Disponível em: http://www.planalto.gov.br/ccivil_03/decreto-lei/ Del2848compilado.htm. Acesso em: jun. 2019.

BRASIL. Constituição da República Federativa do Brasil. Brasília-DF, 1988. Disponível em: http://www.planalto.gov.br/ccivil_03/constituicao/constituicao.htm. Acesso em: jun. 2019.

BRASIL. Lei n. 7.210, de 11 de julho de 1984. Lei de Execução Penal. Brasília-DF, 1984. Disponível em: http://www.planalto.gov.br/ccivil_03/leis/L7210.htm. Acesso em: jun. 2019.

BRASIL. Lei n. 9.099, de 26 de setembro de 1995. Dispõe sobre os Juizados Especiais Cíveis e Criminais e dá outras providências. Brasília, DF, 1995. Disponível em: http:// www.planalto.gov.br/ccivil_03/leis/L9099.htm. Acesso em: jun. 2019.

BRASIL. Lei n. 13.140, de 26 de junho de 2015. Dispõe sobre a mediação entre particulares como meio de solução de controvérsias e sobre a autocomposição de conflitos no âmbito da administração pública. Brasília, DF, 2015. Disponível em: http://www.planalto.gov.br/ccivil_03/_Ato2015-2018/2015/Lei/L13140.htm. Acesso em: maio 2019.

CARAVELLAS, Elaine Tiritan. Justiça restaurativa. In: LIVIANU, R. (Cood.). Justiça, cidadania e democracia [on-line]. Rio de Janeiro: Centro Edelstein de Pesquisa Social, 2009. Disponível em: http://books.scielo.org/id/ff2x7/pdf/livianu-9788579820137. pdf. Acesso em: jun. 2019. 
DIAS, Daniel Baliza; MARTINS, Fábio Antônio. Justiça Restaurativa: os modelos e as práticas. BDMAA, Belo Horizonte, [s.d.]. Disponível em: http://www.bdmaa.com. br/artigos/Trab_justica_restaurativa_publ.pdf. Acesso em: jun. 2019.

FOUCAULT, Michel. Vigiar e punir: história da violência nas prisões. Tradução de Raquel Ramalhete. 20. ed. Petrópolis, RJ: Vozes, 1999.

GABBAY, Daniela Monteiro. Mediação \& judiciário no Brasil e nos Estados Unidos: condições, desafios e limites para a institucionalização da mediação no judiciário. Brasília, DF: Gazeta Jurídica, 2013.

JACCOUND, Mylène. Princípios, tendências e procedimentos que cercam a Justiça Restaurativa. Brasília, DF: Ministério da Justiça: PNUD, 2005.

NORONHA, Edgard. Direito Penal. 37. ed. São Paulo: Saraiva, 2003. v. 1.

ORGANIZAÇÃO DAS NAÇÕES UNIDAS (ONU). Resolução 2002/12 - Princípios básicos para utilização de programas de justiça restaurativa em matéria criminal. 37ạ Sessão Plenária 24 de julho de 2002. Disponível em: http://www.juridica. mppr.mp.br/arquivos/File/MPRestaurativoEACulturadePaz/Material_de_Apoio/ Resolucao_ONU_2002.pdf Acesso em: jul. 2019.

QUEIROZ, Cláudia Lemos. Aspectos relevantes do mediador. In: GROSMA, Cláudia Frankel; MANDELBAUM, Helena Gurfinkel (Org.). Mediação no judiciário: teoria na prática e prática na teoria. São Paulo: Primavera Editorial, 2011.

WALGRAVE, Lode. Imposição da restauração no lugar da dor: reflexões sobre a reação judicial ao crime. In: SLAKMON, Catherine; MACHADO, Maíra Rocha; BOTTINI, Pierpaolo Cruz (Org.). Novas direções na governança da justiça e da segurança. Brasília, DF: Ministério da Justiça, 2006. 